\title{
Tvorjenke s pomenom nosilnika lastnosti v novejšem slovenskem besedju (na primeru NSL in SNB)
}

\author{
INES VORŠIČ \\ Univerza v Mariboru, Filozofska fakulteta, Koroška cesta 160, \\ SI-2000 Maribor,vorsic.ines@gmail.com
}

SCN VIII/1 [2015], 119-134

\begin{abstract}
Siloviti ekonomsko-politični in kulturni procesi so na prelomu tisočletja v slovensko okolje vnesli bistvene jezikovne spremembe, ki se zaradi sodobnih komunikacijskih okoliščin intenzivno vključujejo v vsakodnevno jezikovno rabo. Novi jezikovni pojavi vznikajo na vseh jezikovnih ravninah, dinamika razvoja pa je še najbolj razvidna na področju leksike. Prispevek z obrazilnomorfemskega in semantičnega vidika obravnava neologizme s pomenom nosilnika lastnosti in predstavlja aktualna tipična obrazila omenjene pomenske skupine.
\end{abstract}

Fierce economic, political, and cultural processes at the turn of the millennium have brought substantial linguistic changes to the Slovenian environment due to the intensive inclusion of modern communication situations in everyday language use. The new language phenomena emerge at all linguistic levels; the dynamics of development are most evident in the field of lexis. The article discusses neologisms with the meaning of carrier properties from the affix-morpheme and semantic perspective and it represents current typical affixes of mentioned semantic group.

Ključne besede: besedotvorje, izpridevniške izpeljanke, nosilnik lastnosti, neologizmi

Key words: word-formation, de-adjectival derivatives, nomen attibutivum, neologisms

\section{Uvod $^{1}$}

Na prelomu tisočletja je slovenski prostor doživel spremembe, ki so odraz intenzivnih domačih in svetovnih družbenih, kulturnih ter političnih dogajanj,

${ }^{1}$ Prispevek je prirejen del doktorske disertacije, ki je nastala pod mentorstvom red. prof. dr. Irene Stramljič Breznik in je bila javno zagovarjana oktobra 2013. 
takim spremembam pa aktivno sledi tudi jezikovna raba. Novi jezikovni pojavi vznikajo na vseh jezikovnih ravninah, dinamika razvoja pa je najbolj očitna na področju leksike. Pregled večjega fonda novega besedja, ki skupaj z že uslovarjenim besedjem kaže raznolikost sodobnega slovenskega jezika, prinašata dva jezikovna priročnika, in sicer Novejša slovenska leksika (v povezavi s spletnimi jezikovnimi viri) (2009) in Slovar novejšega besedja slovenskega jezika (2012). $\mathrm{Na}$ osnovi novejše tvorjene leksike, zbrane v omenjenih jezikovnih gradivih, prispevek $\mathrm{z}$ besedotvornosemantičnega vidika raziskuje stanje sodobne slovenščine in predstavlja neologizme $\mathrm{z}$ besedotvornim pomenom nosilnika lastnosti, obenem pa nudi vpogled $\mathrm{v}$ kontinuiteto produktivnosti obrazil omenjene pomenske kategorije tvorjenk. V nadaljevanju pa so najprej predstavljene temeljne teoretične in metodološke usmeritve.

\section{Teoretična raziskovalna izhodišča}

1.1 Tvorba besed je temeljna sposobnost vsakega jezika, zato je naloga besedotvorja kot jezikoslovne vede, ki jo zanima, kako se tvorijo besede in kako so tvorjene, da raziskuje sistemske vzorce, po katerih nastajajo besede v sinhronem časovnem preseku, hkrati pa je njena naloga odkrivati tudi inovativne vzorce tvorbe, ki jeziku zagotavljajo prožnost in živost (Stramljič Breznik 1994: 2). Sodobna slovenska besedotvorna teorija izhaja iz načel strukturalizma in razumevanja jezika kot sistema s hierarhično urejenimi odnosi. Tako Ada Vidovič Muha kot Jože Toporišič, čeprav se njune teoretične opredelitve na nekaterih mestih razhajajo, in Irena Stramljič Breznik - najvidnejši raziskovalci sodobne tvorbene teorije na Slovenskem, izhajajo iz sinhronega pristopa k besedotvorni obravnavi in poudarjajo strukturni pomen. Temu sledi tudi pričujoča besedotvorna obravnava, ki sloni na sintetičnem skladenjsko-pomenskem oz. pretvorbeno-tvorbenem besedotvorju, kot ga je uveljavila Ada Vidovič Muha (2011). Ker je pretvorbeno-tvorbena jezikoslovna metoda vezana na jezikovni sistem, je skladenjski opis tvorjenke skladenjska podstava (Vidovič Muha 2011: 19), tj. nestavčna podredna besedna zveza (s predvidljivo izjemo), katere predmetno- in slovničnopomenske sestavine so pretvorljive v tvorjenko (Vidovič Muha 2011: 331). Besedotvorna podstava je del tvorjenke, nastal iz neobraziljenih korenskomorfemskih besed v skladenjski podstavi oz. del tvorjenke, na katerega se razvršča obrazilo (Vidovič Muha 2011: 331) in je nosilec konkretnega slovarskega pomena tvorjenke (Vidovič Muha 2011: 106). Obrazilo, kot ga opredeljuje Vidovič Muha (2011: 331), pa je definicijski del tvorjenke iz enega ali več morfemov kot pretvorba samo slovničnega pomena skladenjske podstave, lahko pa tudi njenega jedra ali razvijajočega člena.

1.2 Največjo pozornost v obravnavi leksikalnega sistema kakega jezika zavzema t. i. osnovni, centralni leksikalni fond, leksemi, ki mu pripadajo, pa predstavljajo reprezentativno leksiko tega jezika. Tovrstni leksemi imajo običajno največji semantični potencial, pa tudi najfrekvenčnejšo rabo (Dragićević 2011: 
47). Okoli osredja leksikalnega sistema pa se zbirajo novejše, še neuveljavljene besede, v jezikoslovni stroki imenovane neologizmi. Po mnenju R. Simeona (1969), je neologizem jezikovna novotvorba in še ne splošno sprejeta beseda ali izraz, tvorba in uporaba starih besed v novem pomenu, beseda, ki je nedavno prišla $\mathrm{v}$ jezik. V slovenskih jezikoslovnih priročnikih se neologizem opredeljuje kot nova beseda (SP 2001), še ne splošno uveljavljena beseda ali besedna zveza (SSKJ 1998), v Enciklopediji slovenskega knjižnega jezika (Toporišič 1992: 135) je definirana kot na novo napravljena ali pa na novo rabljena stara beseda oz. besedna zveza, Slovenska slovnica (Toporišič 2000: 130) pa neologizem razlaga kot mlado tvorbo, časovno obarvano besedo, ki s pogostnejšo rabo preide v stilno nevtralno besedje, sicer pa ostane priložnostna. Muhvić Dimanovska (2005) ločuje dva tipa neologizmov - denominativne, $\mathrm{tj}$. poimenovalno potrebne nove besede, in stilistične neologizme, v okviru katerih obravnava tudi t. i. okazionalizme kot izraze, ki jih odlikuje svojstven stil kakega avtorja. Po Hohenhausu (2005: 363-365) so neologizmi besede različnih stopenj ustaljenosti v jezikovni normi in niso nove besede $\mathrm{v}$ absolutnem pomenu, temveč šele naslednja faza $\mathrm{v}$ obstoju besede, ko ta postane sprejeta s strani družbe. Če strnemo, je neologizme mogoče razumeti kot lekseme, ki še niso normativizirani v slovarju, so se pa ustalili v širši družbi, in sicer neodvisno od tega, ali so prevzete ali neprevzete, netvorjene ali tvorbeno motivirane, pretvorbeno-tvorbeno sistemske ali nesistemske, ekspresivizirane ali nevtralne besede. So jezikovno frekvenčni izrazi, s strani družbe že sprejeti in komunikacijsko izkoriščani, niso pa še slovarsko kodificirani.

\section{Gradivna raziskovalna izhodišča}

\subsection{Novejša slovenska leksika (v povezavi s spletnimi jezikovnimi viri) (2009)}

Temeljni gradivni vir dotične besedotvorne obravnave je novejše besedje, kot ga prinaša leksikogramski seznam leksikalne zbirke Novejša slovenska leksika (v povezavi s spletnimi jezikovnimi viri) (2009) (v nadaljevanju NSL). $\mathrm{V}$ nadaljevanju so podani temeljni parametri, ki pojasnjujejo vsebinski in metodološki okvir omenjenega leksikalnega gradiva oz. navajajo kriterije, na osnovi katerih je zasnovan leksikogramski seznam novejšega besedja. Ta se v publikaciji opredeljuje kot seznam določenega leksikalnega fonda, ki je (1) urejen po posebnih, v uvodnih spremnih pojasnilih popisanih oz. podrobneje predstavljenih leksikografskih načelih, ki omogočajo optimalno obvestilnost, koordinirano glede na kako drugo, že objavljeno delo, in (2) pripravljen dvoravninsko, upoštevajoč dva tipa ciljnega uporabnika (poljudni uporabnik/bralec in specializirani raziskovalec, jezikoslovec), ter (3) navezujoč se na vzporedne osvetlitvene razdelke (zlasti na podatke o virih oz. na možnost vpogleda v vire z besedilnimi potrditvami) (Gložančev idr. 2009: 9). Seznam je nabor novejše leksike, ki se je v slovenskem jeziku pojavila v letih na prelomu tisočletja - tako 
še ni vključena v SSKJ, v tem smislu pa pomeni novejše besedje oz. novejšo leksiko. Kot termin pa niti izraz novejše besedje niti izraz novejša leksika nista povsem ustaljena, čeprav sta za označevanje določenega besediščnega segmenta primerna, saj gre za oznako leksike, tj. eno-, dvo- in večbesednih leksemskih enot, z vidika njene (začetne) pojavitve na jezikovnorazvojni časovni osi. Glede na specifične okoliščine jezikovnega prostora je v slovenščini vpeljana takšna dogovorna definicijska opredelitev (Gložančev idr. 2009: 12): »Novejše besedje (novejša leksika) je tisto besedje (tista leksika), ki se je v slovenščini pojavilo oz. uveljavilo v obdobju približno zadnjih dvajsetih let.« Alenka Gložančev tako časovno zamejitev utemeljuje $\mathrm{z}$ dveh vidikov, in sicer (1) navezuje se na družbene spremembe, ki so pogojene predvsem z osamosvojitvijo Slovenije, (2) sovpada z izidom zadnje knjige SSKJ, ki velja za temeljni razlagalni slovar, v katerem je že uslovarjena glavnina slovenskega besedja. Dodatni kriterij za oznako novejšega besedja (novejše leksike) je namreč (̌̌e) neuslovarjenost besede v SSKJ. Leksikogramski seznam tako zajema novejše besedje, ki ima sorazmerno visoko stopnjo aktivne jezikovne rabe $\mathrm{v}$ pisnem in govornem prenosniku, povprečen govorec pa se z njim srečuje vsaj pasivno ob uporabi različnih socialnih in funkcijskih zvrsti. $Z$ vidika generiranja izhaja novejša leksika iz desetih osnovnih skupin, ki jih avtorji (Gložančev idr. 2009: 37-39) opredelijo kot: (1) rezultat poimenovalne potrebe za nov ali na novo identificiran predmetni oz. pojmovni denotat, pri čemer je leksem lahko nov izraz (npr. protivirusnik) ali novoopomenjeni izraz oz. neosemantem (npr. miška, ježek); (2) posledica globalizacijskih ali medkulturnih povezav, kar se odraža v močnem prevzemanju angleškega izrazja (npr. brainwashing, coaching) oz. v pojavu besed za označevanje predmetnosti in pojavnosti iz drugih kultur (npr. feta, origami); (3) prikaz slovenskih ustreznic za prevzeto leksiko (npr. medmrežje, napevek); (4) posledica determinologizacijskih procesov (npr. antioksidant, forenzik); (5) rezultat novejše tvorbe iz leksike (npr. aferaštvo, dejavujevstvo); (6) posledica reaktualizacije, pogojene $z$ družbeno-gospodarskimi spremembami (npr. borzništvo, koncesnina); (7) rezultat poobčnobesedenja lastnoimenskega leksema (npr. barbika, frutek); (8) izkaz pisnih realizacij govorjenih kratičnih oblik in tvorjenk iz njih (npr. cedejka, dedevejevski, eldeesovec); (9) rezultat močnega frekvenčnega porasta sicer že ustaljenega besedja (npr. galeristka, kredibilnost); (10) t. i. potencialno novejšo leksiko, ki predstavlja le manjše sistemske (pravopisnonormativne) prilagoditve (npr. alufolija, olimpijada). Seznam NSL vsebuje okrog 15.900 eno- in večbesednih leksemov, v obravnavo pa so zaradi besedotvornega značaja vključeni samo enobesedni leksemi s pomenom nosilnika lastnosti.

\subsection{Slovar novejšega besedja slovenskega jezika (2012)}

Ob koncu leta 2012 je izšel Slovar novejšega besedja slovenskega jezika (v nadaljevanju SNB), ki so ga zasnovali znanstveni in strokovni sodelavci Inštituta za slovenski jezik Frana Ramovša ZRC SAZU na osnovi zbirke novejšega 
besedja, nastale v okviru projekta Novejša slovenska leksika (v povezavi s spletnimi jezikovnimi viri). Slovar, ki z uporabo korpusnega gradiva sledi novim slovaropisnim smernicam, vseh besed leksikogramskega seznama ne zajema, kljub temu pa nudi »vpogled v obsežen fond novih, živih besed, ki skupaj z besedjem, predstavljenim v SSKJ, odstirajo bogastvo in raznolikost sodobne slovenščine« (Bizjak Končar in Snoj 2012). Oblikovan je tako, da se navezuje na SSKJ oz. priteguje v obravnavo v SSKJ že zabeleženo besedje. Pojem novejše besedje tako ni omejen le na nova poimenovanja nove predmetnosti oz. pojavnosti, ampak je »posledica pomenskih, besedotvornih in frazeoloških dogajanj v jeziku samem« (Bizjak Končar in Snoj 2012). Slovar vsebuje 5384 slovarskih sestavkov, ki interpretirajo 6512 pomenov in podpomenov aktualnih besed in tudi besednih zvez z najrazličnejših področij družbenih dejavnosti, v pričujočo raziskavo pa so vključeni samo leksemi, ki besedotvornopomensko ustrezajo kategoriji izpeljank, imenovani nosilnik lastnosti.

\section{Izpeljanke s pomenom nosilnik lastnosti}

V pomensko skupino nosilnik lastnosti se uvrščajo vse tvorjenke, ki so nastale iz pridevniške podstave in imajo podspolsko lastnost neživo oz. nečloveško, neživalsko. Čeprav je za rastline značilna biološka živost, se navadno dojemajo kot akinetična pojavnost ter so s tega vidika bližje predmetom, zato se prav tako uvrščajo v to pomensko skupino. Dodaten razlog je sklanjatveni vzorec, v katerem se pri moškem spolu ujemata imenovalnik in rodilnik, kar jih oddaljuje od vzorca, značilnega za poimenovanja živih bitij, kjer se rodilnik ujema s tožil-

nikom. Tvorjenke s pomenom nosilnika lastnosti tako nastajajo s transformacijo skladenjske podstave $t i s t i-\check{z}$, ki je Prid., npr. tisti-ž, ki je trebušen $\rightarrow$ trebušnjak.

\subsection{Obrazila s pomenom nosilnika lastnosti $(\mathbf{N}-z ̌)$}

V nadaljevanju so predstavljena $\mathrm{v}$ sodobni slovenščini produktivna moško- in ženskospolska obrazila pomenske kategorije nosilnik lastnosti.

\subsubsection{Moškospolska obrazila}

$-\varnothing$

Ničto obrazilo v Slovenski slovnici (Toporišič 2000) še ni zaznano kot tvorno za to pomensko skupino, v leksikogramskem seznamu pa je potrjeno dvakrat, in sicer v tvorjenkah analog $\leftarrow$ tisti-z, $k i$ je analogen 'spojina s podobno strukturo' in multipraktik $\leftarrow$ tisti-ž, ki je multipraktičen. Na tem mestu se tvorjenka multipraktik razume kot gospodinjski aparat, sicer pa lahko tvorjenka ekspresivizirano poimenuje osebo, ki zna stvari zmeraj dobro narediti. 
-ec

S priponskim morfemom -ec je v pomenski skupini nosilnik lastnosti tvorjenih več tvorjenk. Primeri kažejo, da se -ec načeloma pripenja pridevniškim podstavam na -en (npr. digitalec $\leftarrow$ tisti-ž, ki je digitalen, dolgometražec $\leftarrow$ tisti-ž, ki je dolgometražen, daljinec, eksterec, enoprostorec, kompatibilec, lokalec, minimalec, mobilec, popravec, regionalec 'regionalno vozilo', sprejemec, vzajemec), pridevnik na -ski pa je kot podstava manj pogost: maturanec $\leftarrow$ tist $i-\check{z}$, ki je maturantski. Iz primerov je prav tako razvidno, da so podstavni pridevniki lahko v osnovi prevzeti in združeni z domačim priponskim obrazilom -en (npr. eksterec, minimalec), tudi neprevzeti pa so navadno izpeljani (npr. popravec, sprejemec). V samo enem primeru je podstavni pridevnik zložen (enoprosto$r e c)$. Izkaže pa se -ec tudi kot sorodno obrazilo -ik, npr. digitalec : digitalnik, mobilec : mobilnik. Po oznakah SNB (2012) se tvorjenkam z -ec pripisuje pogovornost, medtem ko so tvorjenke $\mathrm{z}-i k$ brez kvalifikatorske oznake in so torej nevtralne.

-ič

Obrazilo -ič je potrjeno trikrat. Tako so priponjene prevzete podstave, slovenščini prilagojene z domačim pridevniškim obrazilom. Tvorjenka krimič $\leftarrow$ tisti-ž, ki je kriminalen je izpeljana iz pridevniške izpeljanke s pripono -en. Tvorjenki pornič $\leftarrow$ tisti-ž, ki je pornografski in psihič $\leftarrow$ tisti-ž, ki je psihološki 'psihološki film' izhajata iz pridevniških tvorjenk na - $(s / \check{s}) k i$, podstavi pridevnikov sta afiksoidno zloženi. Kot je opaziti, je za tovrstno priponjanje značilna močna odzadnja krnitev podstave (krim-, porn-, psih-). Glede na to, da se je okrnjenka porno < pornografski v jeziku že ustalila in jo kot samostojni leksem beleži tudi SNB (2012), bi bilo mogoče ob tvorjenki pornič predvidevati tudi skladenjsko podstavo z okrnjenim pridevnikom tisti-ž, ki je porno. Pomensko se prav vse tvorjenke nanašajo na žanrsko zvrst filma. Pri tem ima krimič že tudi uslovarjeno ženskospolsko sopomenko kriminalka. Pomen vseh tvorjenk je bil korpusno preverjen. Ugotovljeno je bilo, da se lahko poimenovanje psihič nanaša tudi na osebo s psihičnimi motnjami, krimič pa na kriminalista.

\section{$-\mathbf{i j}$}

Z obrazilom -ij se pojavi tvorjenka akcesorij $\longleftarrow$ tisti-z, ki je akcesoren 'dodatek, dopolnilo'. Gre za izpeljavo iz hibridne tvorjenke, katere korenski morfem je latinski. Take tvorjenke so morebiti kot tvorjenke v slovenski jezik že prevzete in nato obrazilno prilagojene, ker pa jih je mogoče razložiti tudi slovensko sistemsko, jih vpeljujemo v obravnavo.

\section{-jak}

Priponsko obrazilo -jak se z le tremi pojavitvami ne uvršča med rodnejša obrazila za nosilnik lastnosti. Tvorjenka gumenjak $\leftarrow$ tisti-ž, ki je gumen je nastala iz izpeljane pridevniške podstave, prav tako tudi tvorjenka trebušnjak $\leftarrow$ tist $_{-z ̌ z}$, ki je trebušen. Izpeljanka pornjak pa je tvorjenka, nastala iz okrnjene pridevniške podstave porno < pornografski. Kot je sklepati iz leksikogramskega 
nabora NSL (2009), kot prej omenjeno, se je okrnjeni pridevnik porno v rabi že ustalil kot samostojni leksem. Sicer se zdi, da ima tvorjenka pornjak slabšalni stilni prizvok - v leksikogramskem naboru je potrjena tudi sinonimna tvorjenka pornič, ta je tudi veliko bolj frekvenčna. ${ }^{2}$

\section{-ik}

Najrodnejše obrazilo v skupini, ki vsebuje poimenovanja za nosilnik lastnosti, je obrazilo -ik. Že doslej je bilo obrazilo opredeljeno kot sploh najrodnejše obrazilo moškega spola za izpridevniške samostalniške izpeljanke (Stramljič Breznik 1994: 55), novejši nabor besedja pa to le še dodatno potrdi. V skladenjski podstavi se kot jedro navadno nahajajo domači (npr. besedilnik, brisalnik, brkljalnik, obvestilnik, ohranjevalnik, trkalnik, zalivalnik), v manjši meri pa tudi prevzeti, slovenščini prilagojeni pridevniki (npr. digitalnik, konkordančnik, prestižnik, modelirnik). Z vidika izglasne tipskosti so tovrstne izpeljanke $\mathrm{v}$ sodobnem času podstavno načeloma omejene na pridevnike, ki se končujejo na -en (npr. dostavnik, komolčnik, masažnik), -(a)len (npr. bivalnik, čofotalnik, črkovalnik, dirkalnik, določevalnik, igralnik, kodralnik, namakalnik, obsevalnik, odzračevalnik, poganjalnik, ponavljalnik, potovalnik, prestrezalnik, sedalnik, varčevalnik, vzpenjalnik, zatemnjevalnik), -(i)len (npr. družilnik, krožilnik, obvestilnik, opozorilnik, praskalnik, razkužilnik), -oven (npr. podatkoven). Le primer avtomatik $\leftarrow$ tisti-ž, ki je avtomatski 'avtomatsko vozilo' ima podstavni pridevnik na -ski. Kar se tiče tvorjenosti podstavnih pridevnikov, ki so motivirajoči za izpeljanke $\mathrm{z}-i k$, gre največkrat za izsamostalniško in izglagolsko izpeljane pridevnike, podstava motivirajočih pridevnikov pa so lahko tudi zloženke (npr. dvonadstropnik, enozvezkovnik, kratkometražnik, nizkocenovnik) ali tvorjenke iz predložne zveze (npr. brezplačnik). Večina navedenega besedja označuje sicer dvobesedno oz. besednozvezno poimenovanje kakega predmeta, priprave, npr. digitalnik-digitalni fotoaparat, dlančnik-dlančni računalnik, masažnik-masažni aparat, mobilnik - mobilni telefon, sekljalnik - sekljalni aparat. Zato so tovrstne tvorjenke v SNB (2012) pogosto zabeležene s pripisom univerbizirano (iz), npr. »masažnik /.../ E univerbizirano iz masažni aparat« (SNB 2012: 212). Kot je zapisano v pojasnilih o zgradbi slovarja, imajo tako sintagmo iztočnice, pri katerih se jedrna beseda prvotne besedne zveze poobrazili in pri tem obrusi. $\mathrm{Ob}$ tem se poraja vprašanje, zakaj imajo tako oznako le nekatere tvorjenke, ne najdemo pa pripisa npr. ob geslu narekovalnik ali dirkalnik, ki sta prav tako stalni besednozvezni poimenovanji, npr. dirkalni avtomobil, narekovalni aparat. Na splošno je univerbizacija v jezikoslovni literaturi večkrat opredeljen pojem, vendar tudi različno in pogosto nejasno opredeljen. Enostavna definicija je sledeča: pojem univerbizacija ali tudi univerbacija (Ćorić 1996, Otašević 1997, Šehović 2012) je poimenovanje za besedotvorni proces, s katerim se besedna zveza pretvori v eno besedo s pomočjo besedotvornega formanta (Ćorić 1996: 61), taka tvorjenka pa se imenuje univerb. Ripka in Imrichová (2011: 49)

\footnotetext{
${ }^{2}$ Po podatkih korpusa Gigafida ima pornjak le 62 pojavitev, medtem ko jih ima pornič kar 3426.
} 
opredeljujeta univerbizacijo kot kondenzacijski proces, pri katerem iz večbesednih poimenovanj nastane eno. V slovenski lingvistični literaturi se je za termin univerbizacije ustalilo poimenovanje poenobesedenje. Jezikoslovci so si enotni $\mathrm{v}$ pojmovanju univerbov kot enot sekundarne nominacije nečesa, kar je v jezi$\mathrm{ku}$ že poimenovano. Kot $\mathrm{v}$ samem poimenovanju pa so opazne razlike tudi $\mathrm{v}$ definiranju motiviranosti univerbov. Božo Ćorić (1996) pojmuje univerbizacijo kot primarno sredstvo racionalizacije $\mathrm{v}$ uporabi jezikovnih sredstev, medtem ko Ristićeva (1995) univerbizacijo dojema kot sredstvo ekspresivizacije. S tem se strinja tudi Amela Šehović (2012), ki meni, da univerbi v odnosu s podstavo razvijajo dodatni konotativni pomen, v čemer se kaže težnja po ekspresivizaciji. Odgovor na vprašanje motivacije nastanka t. i. univerbov je torej jezikovna gospodarnost na eni strani in ekspresivizacija leksike na drugi.

Pojmu univerbizacija se namenoma izogibamo iz dveh razlogov: prvič zaradi neustaljenosti pojma $\mathrm{v}$ slovenski besedotvorni disciplini in drugič zaradi pomanjkanja jasno opredeljene definicije, ki bi podprla enoumno razumevanje in označevanje takih »univerbiziranih« tvorjenk. Namreč, splošna opredelitev univerbizacije kot procesa, s katerim se besedna zveza s pomočjo besedotvornega sredstva pretvori $\mathrm{v}$ eno besedo, je zelo široka, saj so ne nazadnje tudi zloženke, sestavljenke in modifikacijske izpeljanke rezultat poenobesedenja oz. potemtakem univerbizacije, npr. biopridelava - biološka pridelava, kavopivec - pivec kave; naddržava - višja država, neuporabnik - nasprotni uporabnik; podjetnica - ženski podjetnik, tip ček - ljub/mlad tip. Ripka in Imrichová (2011: 49) kot tip univerbizacije opisujeta celo substantivizacijo pridevniškega določila $\mathrm{v}$ podstavni besedni zvezi - v slovenščini se taka tvorba prepoznava kot konverzna izpeljavna.

\section{-nik}

$\mathrm{S}$ sestavljenim priponskim obrazilom -nik je v pomenski skupini nosilnik lastnosti izpeljana le ena tvorjenka, njena podstava se končuje na -t: oprijetnik $\leftarrow$ tisti-ž, ki je oprijet 'oprijet del ženskega perila'.

\subsection{2 Ženskospolska obrazila}

Medtem ko so pri pomenski skupini nosilec lastnosti tvorjenke z ženskospolskimi obrazili izjemno redke - pojavilo se je le obrazilo - $k a$, pa je slika pri nosilniku lastnosti povsem drugačna. Poleg obrazila - ka se pojavljajo še -ica, -ina in - $a$. Tak preobrat je pravzaprav pričakovan, vzrok pa ima v podspolski kategoriji neživo, kar pomeni, da tako poimenovana predmetnost ni zavezana naravni spolski parnosti bitij.

$\mathbf{- a}$

Ženskospolska pripona - $a$ se druži s hibridnimi pridevniškim podstavami $\mathrm{z}$ izglasjem na -en - le-to se odpahne, obrazilo - $a$ pa se nato pripenja prevzeti besedotvorni podstavi: ekskluziva $\leftarrow$ tista-ž, ki je ekskluzivna, marginala $\leftarrow$ 
tista-ž, ki je marginalna, naiva $\leftarrow$ tista-ž, ki je naivna, paliativa $\leftarrow$ tista-ž, ki je paliativna. Podstavni pridevniki so lahko tudi zloženi: trilaterala $\leftarrow$ tista-ž, ki je trilateralna, enako še štirilaterala. Eno pojavitev ima obrazilo - a, ki je nastalo s konverzijo - vozniška (izkaznica).

\section{-ica}

Med rodnejšimi ženskospolskimi obrazili za nosilnik lastnosti je tudi obrazilo -ica. Ugotavljamo, da se v podstavah izpeljank navadno pojavljajo desubstantivno (npr. jeklenica, limonadnica), deverbativno (npr. določnica, dovoznica) in tudi deadverbialno (npr. enkratnica, pokončnica) tvorjeni pridevniki. Večinoma so izpeljani (npr. kratičnica, priložnostnica), lahko pa tudi zloženi (npr. enakoizraznica, štirisedežnica). Obrazilno so podstavni pridevniki lahko sledeči: -en (npr. cvetličnica, kratičnica, drobižnica, oprsnica, prosojnica), -oven (npr. časovnica, dvopasovnica), -(a/i)len (npr. nanašalnica, večalnica). Kar nekaj tvorjenk je z jezikoslovnega strokovnega področja: enakoizraznica, enakopisnica, enkratnica, kratičnica, nanašalnica, priložnostnica, večalnica, večnaglasnica. Veljalo bi izpostaviti tvorjenko potičnica 'posoda za peko potice' $\leftarrow$ tista-ž, $k i$

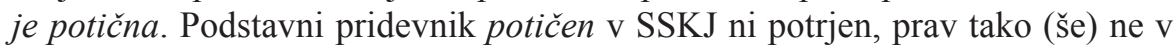
SNB (2012), v korpusu pa vendarle ima več pojavitev (npr. potična komisija 'komisija za oceno potice', potični rum, potično testo, potični zvitek). Enako velja za tvorjenko izskočnica $\leftarrow$ tista-ž, ki je izskočna (npr. v zvezah izskočno okno, izskočna antena, izskočna mrežica, izskočna bliskavica). Posebej zanimiva pa je tvorjenka z dvojničnim zapisom ledica oz. LEDica - prav zadnji zapis poudarja tujo kratično podstavo LED (angl. light-emitting diode), ki ji je pripeto obrazilo -ica. Kratica nekoliko presenetljivo še ni zajeta v SNB (2012), korpus pa ponudi večje število zadetkov, v katerih se kratica pojavlja kot prvi del zloženk, npr. LED-bliskavica, LED-lučka, LED-projektor, LED-svetilka, LED-tehnologija, LED-zaslon, LED-žarnica.

\section{-alija}

Z enkratno pojavnostjo je potrjena pripona -alija - združena je s prevzeto besedotvorno podstavo oz. je pretvorba skladenjske podstave tista-ž, ki je eksterna $\rightarrow$ eksternalija.

\section{-ilija}

Potrjeno je tudi obrazilo -ilija, ki pa se s skromno pojavnostjo ravno tako ne uvršča med plodna obrazila. Primer je tvorjenka memorabilija $\leftarrow$ tista-ž, ki je memorabilna. Gre za hibridno tvorjenko s prevzeto besedotvorno podstavo. Pomensko se tvorjenka nanaša na raznolike spominke.

\section{-ka}

Tvorjenk, ki s pridevniško podstavo in obrazilom - $k a$ poimenujejo ženskospolsko predmetnost, je v leksikogramskem gradivu precej. Opaziti je, da gre podstavno največkrat za izpeljane pridevnike (npr. barvanka, navedenka, gorenjka, šumenka, tiskovka ipd.), lahko pa tudi zložene (npr. devetletka, mikrovalovka, 
novotvorjenka, triletka) ali celo sestavljene (npr. anonimka, nadnacionalka, transnacionalka). Podstavni pridevniki so navadno deverbativni pridevniki z izglasjem na -(ov)en (npr. naslovka, okrnjenka, prepognjenka, prevedenka, raztegnjenka, spalka, tiskovka, vinilka, zgoščenka), -(a/i)len (npr. ležalka, prisilka, razvedrilka, socialka), -n (npr. kŕpanka, mečkanka, zavozlanka), -onalen (npr. nacionalka, regionalka), -av (npr. bliskavka), -ljiv (npr. žgečkljivka), -i (npr. minika). Lahko pa gre tudi za desubstantivne vrstne pridevnike na -ski (npr. dolenjka, makadamka) in celo svojilne -(elo)v (npr. kalašnikovka, šubička). Podstave so torej lahko tako prevzetega (npr. mikrovalovka, transnacionalka ipd.) kot domačega izvora (npr. žgečkljivka, zgoščenka ipd.). Pomensko gre $\mathrm{v}$ tej skupini za tvorjenke, ki so zelo raznolike - npr. anonimka je anonimno pismo, naslovka naslovna stran, socialka socialna pomoč, spalka spalna vreča, šumenka šumena tableta, tiskovka tiskovna konferenca, vinilka vinilna plošča ipd. Velikokrat pa tvorjenke poimenujejo tip prometnih cest, npr. magistralka, regionalka, makadamka, ki so lahko poimenovane tudi glede na smer, v kateri peljejo, npr. dolenjka, gorenjka. Več tvorjenk je tudi z jezikoslovnega področja, npr. istopomenka, navedenka, novotvorjenka, okrnjenka, prevedenka. Pretirane zaznamovanosti v tej skupini ni zaslediti, izpostaviti je mogoče le pogovorno zaznamovanost, ki se ohranja iz podstave, npr. minika. Zanimivejša je s tega vidika tvorjenka žgečkljivka, ki pa ekspresivno poimenuje kako stvar z erotično vsebino. Dodatno razlago pa potrebuje še obrazilo $-k a$ v primeru tvorjenke kaprijka(-e) $\leftarrow$ tist(a/e)-ž, ki so kapri. Pridevniška raba besede kapri je že potrjena v SNB (2012), medtem ko besede v SSKJ ni mogoče najti - gre za pridevnik, prevzet prek angleščine po imenu otoka Capri. Navadno se nanaša na obleko, ki je na tri četrt navadne dolžine hlačnic, npr. kapri pižama $\rightarrow k a-$ prijka, tudi ob srednjespolskih (npr. kapri krilo) in množinskih samostalnikih (npr. kapri hlače $\rightarrow$ kaprijke).

\section{-ina}

Produktivno ženskospolsko priponsko obrazilo za nosilnik lastnosti je -ina, ki ima v tej pomenski skupini 11 potrditev. Kot rodnejše obrazilo je pripono -ina v svoji disertaciji Prvostopenjske izpridevniške tvorjenke navajala tudi Irena Stramljič Breznik (1994: 56), ki je ugotavljala, da so lahko v podstavi prav vsi pomenski tipi pridevnikov, tvorjeni na -ən/-en, -av/-ev, -at, -əl; -i, -ji, -ski; -ov/ev, poleg tega so podstave lahko prvotnopridevniške ali zaimenske. Vzorec sodobnega besedja je manjš̌i, ${ }^{3}$ daje pa nekoliko drugačne podatke. Izkaže se namreč, da se $\mathrm{v}$ novejši slovenščini tovrstno obrazilo pripenja deverbativnim ali desubstantivnim pridevniškim podstavam na -en (dednina $\leftarrow$ tista-z, $k i$ je dedna, priključnina, embalažnina, frekvenčnina, garažnina, izpitnina, licenčnina, omrě̌nina, števčnina), v enem primeru na -(a)len (igralnina). Iz navedenih primerov je razvidno, da gre za tvorjenke, ki imajo leksikalni pomen 'dajatev'. Kot piše Irena Stramljič Breznik (1994: 57) je del tvorjenk zaradi pomenskosti

\footnotetext{
${ }^{3}$ Raziskava Irene Stramljič Breznik (1994) temelji na besedju SSKJ I-V, Pleteršnikovega Slovensko-nemškega slovarja (1894-1895) in Besedišča slovenskega jezika.
} 
in rabe omejen zgolj na knjižni jezik, obenem pa se v delu izpeljank odražajo spremenjene družbene okoliščine, zaradi česar so v besediščni celoti jezika odmaknjene v skupino zastarelih oz. starinskih besed. V sodobnejšem času pa lahko govorimo o ponovni oživitvi tovrstnih izrazov. Medtem ko SSKJ na primer besedo gozdnina 'pristojbina za izkoriščanje gozda 'označuje s kvalifikatorjem zastarelo, so tvorjenke s pomenom pristojbine danes znova zelo žive (npr. embalažnina 'pristojbina za zbiranje in predelavo odpadne embalaže', frekvenčnina 'plačilo za uporabo frekvence', garažnina 'pristojbina za uporabo garaže', izpitnina 'pristojbina za pristop k izpitu', licenčnina 'plačilo za pridobitev, uporabo licence', omrežnina 'plačilo za uporabo energetskega omrežja', priključnina 'plačilo za priključek', števčnina 'plačilo za uporabo števca'). Živost obrazila -ina s pomenom dajatve ne nazadnje dokazujejo tudi korpusni primeri, npr. drsalnina, jahalnina, potovalnina, straniščnina. Posebej zanimiva je tvorjenka šankarnina, ki ima razširjeno obrazilo -arnina - tvorjenka je nastala analogno po zgoraj omenjenih, ohranja pa socialnozvrstno zaznamovanost kot nižje pogovorna. Pomeni pristojbino za uporabo šanka oz. točilnega pulta. Ker se nanaša na pretirano rabo alkohola, ji je mogoče pripisati tudi emotivno zaznamovanost.

\subsubsection{Sinteza obrazilne produktivnosti v pomenski skupini nosilnik lastnosti}

Predstavili smo v novejši slovenščini produktivna moško- in ženskospolska obrazila izpridevniških izpeljank s pomenom nosilnika lastnosti, sledi pa sinteza rodnosti obrazil, in sicer primerjalno $\mathrm{z}$ obrazili, ki jih $\mathrm{v}$ okviru iste pomenske skupine navaja Slovenska slovnica (Toporišič 2000). To nudi uvid v kontinuiteto produktivnosti obrazil tovrstnih izpeljank. Obrazila v razdelku NSL (2009) so razvrščena padajoče od najproduktivnejšega $\mathrm{k}$ manj produktivnemu, medtem ko so obrazila iz Slovenske slovnice (Toporišič 2000) zabeležena neodvisno od kriterija frekvenčnosti - slovnica namreč ne ponuja frekvenčne analize produktivnosti, ki bi omogočala izpostavitev najproduktivnejšega oz. najmanj produktivnega obrazila.

\subsubsection{Sinteza obrazilne produktivnosti moškospolskih obrazil v pomenski skupini nosilnik lastnosti}

Iz tabele 1 je razvidno sledeče: medtem ko je v Slovenski slovnici (Toporišič 2000) navedenih 8 tvornih obrazil, jih danes lahko naštejemo 7. Kontinuiteta je vidna ob obrazilih $-i k,-e c,-i c ̌$, -jak, plodnost pa so izgubila obrazila $-i,-a r i j$ in $-u \check{s}$.

Razliko v rodnosti obrazil pomenske skupine nosilnik lastnosti je pričakovano mogoče opaziti tudi, če se ozremo še bolj v zgodovino, k Pleteršnikovemu Slovensko-nemškemu slovarju (1894/95). Obrazila s pomenom nosilnika lastnosti, potrjena v njem, je mogoče najti pri Antonu Bajcu (1950), ki je besedotvorno 
teorijo zasnoval prav na osnovi besedja Pleteršnikovega slovarja. Pri Bajcu (1950) najdemo skupaj devet obrazil: -c (npr. mokrc), -ec (npr. iglavec), -ič (npr. drobnič), -ek (npr. toplek), -ik (npr. delavnik), -nik (npr. ajdovnik), -ak (npr. kravjak), -ščak (npr. konjščak) in -jak (npr. beljak). Danes rodna obrazila, ki so zabeležena že pri Bajcu (1950), so -ik, -ec, -jak, -ič in -nik. Tem obrazilom je torej mogoče pripisati tvorbeno kontinuiteto, ki pa lahko distribucijsko niha. Rodnost so v primerjavi z Bajčevim seznamom obrazil za ta besedotvorni pomen povsem izgubile pripone $-c,-a k$ (Toporišič (2000) jo še navaja) in -ščak.

Tabela 1: Produktivnost moškospolskih obrazil s pomenom nosilnik lastnosti ( $N-z ̌)$

\begin{tabular}{|c|c|}
\hline SS (2000) & NSL (2009) \\
\hline$-e c$ & $-i k$ \\
\hline$-i c ̌$ & $-e c$ \\
\hline$-i$ & $-j a k$ \\
\hline$-a r i j$ & $-i c$ \\
\hline$-a k$ & $-\varnothing$ \\
\hline$-j a k$ & $-n i k$ \\
\hline$-i k$ & $-i j$ \\
\hline$-u \check{s}$ & \\
\hline & \\
\hline
\end{tabular}

Produktivnost današnjih obrazil za tvorbo s pomenom nosilnik lastnosti prikazujemo še grafično. Danes je najvišjo stopnjo tvorjenosti mogoče zaznati pri obrazilu -ik - tvorjenke z -ik predstavljajo kar 77-odstotni delež v tej skupini tvorjenk. Na drugem mestu je obrazilo -ec (13,8 \%), ostala obrazila pa so slabše plodna oz. imajo le skromno potrditev.

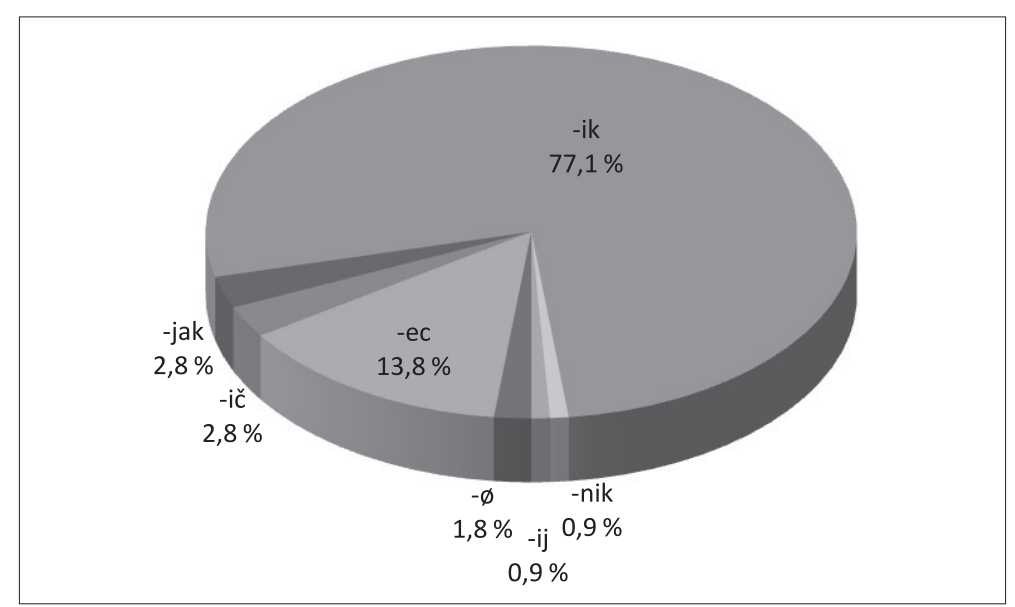

Grafikon 1: Grafični prikaz produktivnosti moškospolskih obrazil s pomenom nosilnik lastnosti ( $N-\check{z})$ 
3.1.3.2 Sinteza obrazilne produktivnosti ženskospolskih obrazil v pomenski skupini nosilnik lastnosti

Tabela 2: Produktivnost ženskospolskih obrazil s pomenom nosilnik lastnosti ( $N-\check{\text { ) }}$ )

\begin{tabular}{|c|c|}
\hline SS (2000) & NSL (2009) \\
\hline$-a$ & $-k a$ \\
\hline$-i c a$ & $-i c a$ \\
\hline$-a d a$ & $-i n a$ \\
\hline$-u l j a$ & $-a$ \\
\hline$-u r i j a$ & $-a l i j a$ \\
$-k a$ & $-i l i j a$ \\
$-i k a$ & \\
$-i n a$ & \\
\hline
\end{tabular}

V Slovenski slovnici (Toporišič 2000) je v pomenski skupini za nosilnik lastnosti zabeleženih 9 ženskospolskih obrazil. Za novotvorjeno leksiko jih je danes produktivnih 6 , vendar so med temi tudi nekatera nova, prevzeta obrazila, ki se tudi družijo zgolj s prevzetimi besedotvornimi podstavami, tj. -alija, -ilija. Netvorne za novejšo leksiko so -ada,-ulja, -urija in -ika. Tvorbeno kontinuiteto pa izkazujejo - $a$, -ica, $-k a$ in -ina.

V primerjavi z Bajčevim (1950) seznamom ženskospolskih obrazil s pomenom nosilnika lastnosti, so opazne precejšnje razlike, saj je Bajec na osnovi besedja Pleteršnikovega slovarja prepoznal le štiri ženskospolska obrazila, in sicer: -ica (npr. levica), -ina (npr. bakrenina), -ka (npr. fižolovka) in -ika (npr. mladika). Vsa obrazila, razen priponskega morfema -ika, so obdržala svojo rodnost.

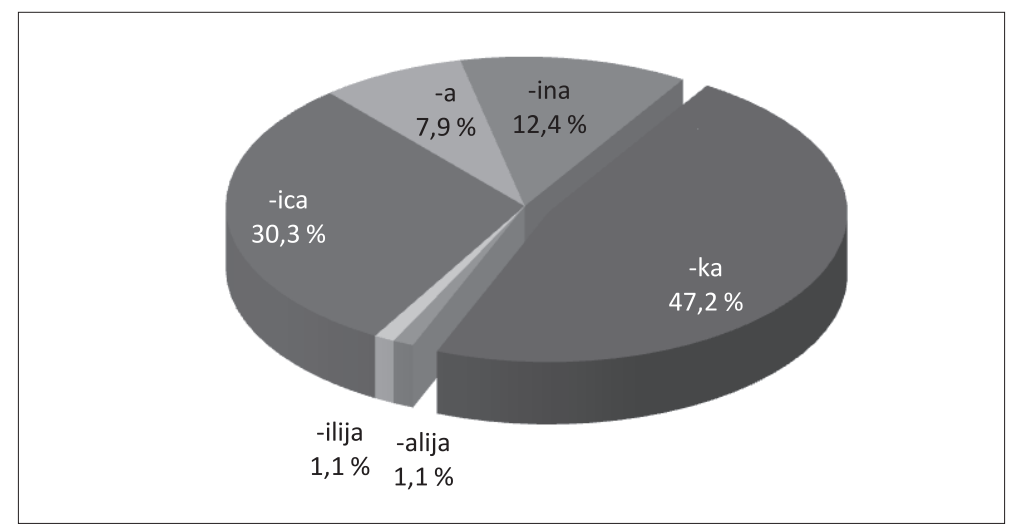

Grafikon 2: Grafični prikaz produktivnosti ženskospolskih obrazil s pomenom nosilnik lastnost $(N-\check{z})$ 
Danes je, kot ponazarja grafikon 2, najrodnejše obrazilo - ka (47,2 \%), sledi - ca $(30,3 \%)$, nato -ina $(12,4 \%)$ in $-a(7,9 \%)$. Prevzeti obrazili -alija in -ilija imata zgolj po eno potrditev. ${ }^{4}$

\section{Sklep}

Osrednji namen prispevka je na osnovi novejšega besedja, kot ga beležita $\mathrm{No}$ vejša slovenska leksika (2009) in Slovar novejšega beseda slovenskega jezika (20012), tipološko predstaviti tvorbene lastnosti novoustvarjene slovenske leksike $\mathrm{z}$ besedotvornim pomenom nosilnik lastnosti, $\mathrm{v}$ okviru tega pa raziskati in popisati novejša tvorbena obrazila, dognati, katera so posebej tvorna, katera so svojo rodnost izgubila. Ob tem smo dodatno obravnavali še okazionalno besedje.

Za tvorbo novih izpridevniških samostalnikov, ki se z besedotvornopomenskega vidika uvrščajo v pomensko kategorijo nosilnik lastnosti, je daleč najrodnejše (77,1 \%) obrazilo -ik (npr. besedilnik, obvestilnik, trkalnik), plodnost pa izkazujejo tudi ženskospolska obrazila, zlasti -ka (npr. šumenka) in na novo oživelo obrazilo -ina s pomenom dajatve oz. pristojbine (npr. izpitnina). Če je torej že kazalo, da produktivnost tega tvorbenega vzorca usiha, je sedaj mogoče trditi povsem nasprotno.

Na splošno je v primerjavi s Slovensko slovnico (Toporišič 2000) mogoče ugotoviti manjšo obrazilno razponjenost, kar gotovo izvira iz dejstva, da je tudi vzorec raziskovanega besedja veliko manjši. Zavedati se je potrebno, da nove besede šele skupaj s tradicionalnim ustvarjajo sodobni slovenski jezik - del tega je še zmeraj tudi uslovarjeno besedje, nove besede pa pomenijo zgolj spopolnitev in razširitev leksikalnega polja. Ni torej mogoče reči, da so vsa tu morebiti nezapisana obrazila neobstoječa, le rodna (̌̌e) niso za tvorbo novejše leksike.

$\mathrm{Ne}$ glede na to, ali se bodo tovrstne besede $\mathrm{v}$ jeziku ustalile ali ne, pa se dokazuje, da so domači in tudi prevzeti besedotvorni morfemi plodni za tvorbo novejšega, tako leksikografsko potencialnega kot tudi priložnostnega, efektivno učinkujočega besedja. S tem se potrjuje izrazita živost slovenskega jezika.

\section{VIRI IN LITERATURA}

Anton BAJEC, 1950: Besedotvorje slovenskega jezika I, Izpeljava slovenskih samostalnikov. Ljubljana: Slovenska akademija znanosti in umetnosti.

Aleksandra BIZJAK KONČAR, Marko SNOJ, 2012: Slovar novejšega besedja slovenskega jezika. Ljubljana: Založba ZRC, ZRC SAZU.

Božo ĆORIĆ, 1996: O sufiksalnoj univerbaciji u srpskom jeziku. Srpski jezik 1/1-2, 60-64.

\footnotetext{
${ }^{4}$ Med srednjespolskimi obrazili sta bili skromno rodni le -o in -ilo, danes tovrstnih tvorjenk ne beležimo.
} 
Rajna DRAGIĆEVIĆ, 2011: Leksika kvalifikovana kao individualna u srpskim deskriptivnim rečnicima. Leksikologija. Onomastika. Sintaksa. Zbornik u čast Gordani Vuković. Ur. S. Pavlović, V. Ružić. Novi Sad: Filozofski fakultet. 47-59.

Alenka GLOŽANČEV, Primož JAKOPIN, Mija MICHELIZZA, Lučka URŠIČ, Andreja ŽELE, 2009: Novejša slovenska leksika (v povezavi s spletnimi jezikovnimi viri). Ljubljana: Inštitut za slovenski jezik Frana Ramovša ZRC SAZU.

Peter HOHENHAUS, 2005: Lexicalization and Institutionalization. Handbook of Word-formation. Studies in Natural Language and linguistic Theory. Ur. P. Štekauer, R. Lieber. Berlin, Dordrecht, Heidelberg, Norwell: Springer. 353-373.

Vesna MUHVIĆ-DIMANOVSKI, 2005: Neologizmi. Problemi teorije i primjene. Zagreb: Zavod za lingvistiku Filozofskoga fakulteta Sveučilišta u Zagrebu.

Đorđe OTAŠEVIĆ, 1997: Univerbacija. Naš jezik XXXII/1-2. 52-63.

Maks PLETERŠNIK, 1984-1985: Slovensko-nemški slovar (1894-1895). Transliterirana izdaja na plošči CD-ROM. Ur. M. Furlan idr. Ljubljana: Založba ZRC 2009.

Ivor RIPKA, Mária IMRICHOVÁ, 2011: Kapitoly z lexikológie a lexikografie. Prešov: Prešovská univerzita v Prešove.

Rikard SIMEON, 1969: Enciklopedijski rječnik lingvističkih naziva. Zagreb: Matica hrvatska.

Slovar slovenskega knjižnega jezika z Odzadnjim slovarjem slovenskega jezika in Besediščem slovenskega jezika z oblikoslovnimi podatki. Elektronska izdaja na plošči CD-ROM. Ljubljana 1998.

Irena STRAMLJIČ BREZNIK, 1994: Prvostopenjske izpridevniške tvorjenke: doktorska disertacija. Ljubljana: Filozofska fakulteta.

Amela ŠEHOVIĆ, 2012: Univerbacija u bosanskom jeziku. Tvorba reči i njeni resursi u slovenskim jezicima: zbornik radova sa četrnaeste međunarodne naučne konferencije Komisije za tvorbu reči pri Međunarodnom komitetu slavista. Ur. Rajna Dragićević. Beograd: Filološki fakultet. 407-417.

Jože TOPORIŠIČ, 1992: Enciklopedija slovenskega jezika. Ljubljana: CZ.

- -, 2000: Slovenska slovnica. Maribor: Obzorja.

Ada VIDOVIČ MUHA, 2011: Slovensko skladenjsko besedotvorje ob primerih zloženk. 2. razširjena in dopolnjena izdaja. Ljubljana: Znanstvena založba Filozofske fakultete.

\section{DERIVATIVES WITH MEANING OF NOMEN ATTIBUTIVUM IN LATER SLOVENE VOCABULARY (EXAMPLES: NSI AND SNB)}

Fierce economic, political, and cultural processes at the turn of the millennium have brought substantial linguistic changes to the Slovenian environment due to the intensive inclusion of modern communication situations in everyday language use. The new language phenomena emerge at all linguistic levels; dynamics of development are most evident in the field of lexis. With this in mind, this dissertation lexical study entitled 
"Systemic and non-systemic lexical formation in modern vocabulary of Slovenian language" focuses on word-formation issues that reflect the new language incidences and unstoppable currents of globalization. The starting point of word-formation reading is the material covered in Novejša slovenska leksika (in conjunction with online linguistic resources) (2009) and Slovar novejšega besedja slovenskega jezika (2012), supplemented with a corpus of confirmed and coincidentally obtained occasional derivatives. The article discusses neologisms with the meaning of nomen attibutivum from the affixmorpheme and semantic perspective and it represents current typical affixes of the mentioned semantic group. Using examples of neologisms, the article points out that Slovenian language, despite the intense influence of globalization is often successful in maintaining the formation vitality and draws lexical innovations from both its own and globally independent elements. 